geven wel de contouren van die opvoeringspraktijk aan of, met andere woorden, van het 'visueel en akoestisch potentieel' (96) van de stukken. De rederijkers hadden een heel eigen manier om duidelijk te maken hoe kluchten moesten of konden worden gespeeld: de tekst gold als het ware als ondertiteling van de handeling. Directe regieaanwijzingen in de overgeleverde teksten zijn schaars, maar de personages lichten doorgaans uitvoerig hun plannen en de handelingen die ze stellen toe en geven uitgebreide beschrijvingen van zichzelf en andere personages. Dialoog staat dan ook - in tegenstelling tot bijvoorbeeld het ongeveer contemporaine genre van de commedia dell'arte - centraal in de rederijkerskluchten.

Belangrijk is ook dat de rederijkers als eersten in het Nederlandse taalgebied systematisch hun toneel op schrift stelden en daardoor het spel verankerden in een geschreven, vaste vorm. Want hoe explosief en uitbundig de rederijkerskluchten ook bleken op de toneelpodia, ze waren niet wild of spontaan maar daarentegen zeer bedacht en geconstrueerd.

De studie van Femke Kramer is rijk, zowel qua stijl als inhoud. Door haar scenische leesmethode krijgen we een goed beeld van het visuele en verbale potentieel van het rederijkerstoneel. Toch besteedt ze hier slechts twee hoofdstukken aan. In de andere hoofdstukken worden Kramers ideeën theoretisch onderbouwd. Zo krijgen we een zeer scherpzinnige analyse van Bakhtins ideeën over het 'grotesk realisme'. Jammer is wel dat de meer theoretisch geïnspireerde hoofdstukken te losjes aan elkaar hangen. En hoe rijk dit boek ook is vanuit literair-theoretisch en dramaturgisch perspectief, als cultuurhistorische studie schiet ze mijns inziens toch te kort. Er wordt bijvoorbeeld heel wat voorkennis over de rederijkerscultuur en over de zestiende eeuw in het algemeen verondersteld. Kramer rekent zonder veel genade af met de these van het beschavingsoffensief, maar maakt niet duidelijk waarom ze de rederijkerscultuur zelf als onderdeel van een volkscultuur ziet die zich in de zestiende eeuw door verschriftelijking uit de marge rukte. Ook verklaart ze niet in welke zin, zoals ze stelt, de groteske esthetiek van de rederijkersliteratuur een teken is van een cultuur in verwarring. Ze gaat dan ook grotendeels voorbij aan de vele recente (literatuur-) historische publicaties waarin de onzinnigheid van de tweedeling volkscultuur-elitecultuur als analysekader voor de rederijkersbeweging expliciet aan de orde wordt gesteld en de wisselwerking tussen de rederijkers en de zestiende-eeuwse cultuur vanuit andere perspectieven wordt verkend. Helemaal onbegrijpelijk is dit niet. Zoals de auteur een aantal keren te kennen geeft, verkiest ze de brede diachronische analyses van weleer (met Bakhtin als uitmuntend voorbeeld) boven de huidige tendens in de historische wetenschappen om alles te contextualiseren en vanuit een veeleer kleinschalig perspectief te bekijken. Of de tijd inderdaad rijp is voor een nieuwe paradigmawissel, valt te bezien.

ANNE-LAURE VAN BRUAENE, UNIVERSITEIT GENT

\section{Nieuwe geschiedenis}

\section{Geevers, Liesbeth, Gevallen vazallen. De} integratie van Oranje, Egmont en Horn in de Spaans-Habsburgse monarchie (1559-1567)

(Dissertatie Universiteit van Amsterdam 2008, Amsterdamse Gouden Eeuw reeks; Amsterdam: Amsterdam University Press, 2008, 252 blz., ISBN 978908964069 7).

The conflict between Granvelle the younger and the three leading members of the Council of State has long been seen as the 'voorspel' of the Dutch Revolt. Recently, interpretation of the conflict has have focused on questions of ideology - Granvelle seen as representing a style of government inimical to the traditions of the country - or patronage - Granvelle seen as monopolizing the rights of 
appointment. This book broadens the discussion by concentrating on channels of communication and personal relationships.

Official reports from Brussels passed through the hands of either Charles Tisnaq of Josse de Courteveille, the secretaries for French-language correspondence attached to Philip II's court. But while Tisnacq and Courteville had access to the person of the king, usually after he had met with his Consejo de Estado, they were not admitted to the Consejo, and thus had no opportunity 'om de Nederlandse kwesties met andere raadsheren te bespreken' (59). By default, Margaret of Parma and her key advisers used other channels to make direct contact with their counterparts in Spain. As Geoffrey Parkers and others have noted, the contador Cristobal de Castellanos was particularly important in this respect. And since Castellanos reported to Francisco de Eraso - a partisan of the prince of Eboli, and a foe of Granvelle's great friend, the duke of Alba - historians have seen a parallel between existing factions at the Spanish court and incipient factions in Brussels. Here Geevers offers a useful caution. Eraso did indeed hate Granvelle, but Egmont first addressed him (through Castellanos) not for this reason, but in connection with arrangements for repatriating the two Spanish tercios left behind in the Netherlands after the peace of 1559. The Ebolistas did indeed espouse a 'federalist' understanding of the Spanish monarchy (179), making room for the role that Orange, Egmont and Horn hoped to play in the Netherlands, but they expected the great men of the Low Countries to cooperate on vital issues, notably the king's religious policies.

Netherlands nobles had ties to a world beyond the reach of the Spanish crown, in Germany, whence came many military units and regimental commanders that fought under Orange and Egmont and Horn during the Habsburg-Valois wars. All three men contracted marriages with German princely families, and Orange and Egmont helped persuade Eraso to resume payment of pensions to some thirty imperial princes that had been suspended after the peace of 1559 . Yet the three men also had different degrees of independence from the Spanish connection. While Horn commanded the king's bodyguard in Spain (1549-1561), and Egmont had hoped at one point to be named Viceroy of Naples, Orange 'zag zichzelf liever al een soort rijksvorst' (182). Early in 1561 he married Anna of Saxony, the daughter and granddaughter of Charles V's great enemies in Germany (Maurice of Saxony and Philip of Hesse). Margaret of Parma reacted almost immediately. In April of that year, she entrusted the annual renewal of the magistracy in Antwerp not to Orange - to whom this honor properly belonged, in his capacity as marquis of Antwerp - but to Granvelle. Thus was the first blow struck.

In keeping with his father's precepts, Philip II never completely trusted any of his ministers. In Spain and in his Italian realms he preserved his own freedom of action by playing noble factions off against each other. Geevers suggests that this tactic could not have worked as well in the Netherlands, where, as noted, nobles had other sources of patronage and influence. But my one criticism of this careful and important study is that the author provides no evidence that Philip II ever intended to play Orange and Egmont and Horn off against Granvelle and Viglius. Convening the States General in 1558 had been a rock of division in the Council of State, with Granvelle and Viglius opposed, and Savoy and most of the great nobles in favor. The king sided with the majority but later regretted his decision, and subsequent division of opinion about whether this parliamentary assembly had accomplished anything useful was if anything even sharper. As Geevers notes, when Orange and Egmont and Horn called for a States General in their second letter to Philip (1564), they touched on 'één van de heetste hangijzers in de Brusselse politiek' (103). Might it be said that the quarrel between Granvelle and the great nobles, here treated as beginning in 1559 , had already begun in 1558 ? 
Kaplan, Benjamin, e.a. (eds.), Catholic

Communities in Protestant States: Britain and the Netherlands c.1570-1720 (Studies in Early

Modern European History; Manchester, New York: Manchester University Press, 2009, xIV + 274 blz., ISBN 978071907906 1).

Despite their many similarities, Catholic communities in the early modern England and United Provinces had not yet been systematically compared. With this remarkable volume, proceedings of the sixteenth Britain and the Netherlands conference, this gap has been filled. The editors have planned a balanced comparison which takes into account the most important aspects of what can be called 'minority Catholicism' (Christine Kooi) in both countries: relationship between laity and clergy, coexistence with the Reformed majority, role of women, international connections. In his opening, Willem Frijhoff provides a historiographical survey and drafts a research agenda. He stresses the limitations of the historiography until the 1990s: it was national, adopted an ecclesiastical point of view and conveyed a sense of victimisation. The transformations of religious history in the last decades command, according to Frijhoff, a triple shift: attention to transnational dimensions, comparison of national developments and reconstitution of survival strategies for religious minorities.

The other chapters of the book use these reflexions as - sometimes explicit - starting points. The first chapters (respectively by Charles Parker and Michael Mullett) analyse the relationship between laypeople and clerics. It was conditioned by similar problems: in both cases, due to the Reformation, the Catholic diocesan structure had disappeared and the Catholic Church became a Mission; due to the absence of revenues for priests, they were dependent on patronage by the elites, particularly in England, where many priests lived in gentry homes. There were differences as well: in England, the number of priests was much higher, which led to the formation of a 'clerical proletariat', whereas in the Netherlands, in some areas, such as the Eastern and Northern provinces, there was a shortage of priests. Both authors stress the active role played by the laity - Charles Parker proposes the concept of 'collaborative confessionalisation' to describe the implementation of the Catholic Reformation in the United Provinces.

Other contributions address the relationship between laypeople and clergy, namely those by Joke Spaans and Mary Rowlands, centered on the role of women in both Missions. Joke Spaans shows how important a role lay women could play in the Netherlands: 'spiritual virgins', which led a semireligious life, took care of priests, copied devotional books, taught catechism; the wealthier supported the recruitment of boys for the ministry by donations. Social and family networks connected them to priests. Although England did not have any 'spiritual virgins', women were able to play similar roles: some women belonging to the gentry harboured priests, working women kept alehouses where Masses took places; from the late seventeenth century on, with the growing toleration enjoyed by Catholics, women kept little schools while other worked as housekeepers for priests.

Two other chapters also provide insight into the role of women and the relationship between laity and clergy, although their main focus is on the transnational dimensions of English and Dutch Catholicism: Paul Arblaster and Claire Walker highlight the centrality of the Southern Netherlands for both countries, due, according to Arblaster, to their attractiveness as a Tridentine model and to their willingness to support religious refugees. For Dutch Catholicism, the Spanish Netherlands provided training institutions and cheap editions, whereas for England, they also harboured exiled religious houses; in both cases, lay families took refuge in the Southern Netherlands - some of them, belonging to the aristocracy, received help from the archdukes in the early seventeenth century. Claire Walker's 